\section{Marketisation of adult education in Sweden}

\author{
Per Andersson $\odot$ and Karolina Muhrman $₫$
}

Journal of Adult and Continuing

Education

202I, Vol. 0(0) I-I8

(C) The Author(s) 202I

(c) (i)

Article reuse guidelines:

sagepub.com/journals-permissions

DOI: I0.| |77/|47797|42 | I05549|

journals.sagepub.com/home/adu

(SSAGE

\begin{abstract}
The aim of this study is to analyse how formal adult education in Sweden is enacted locally. For this analysis, the data consist of a nationwide survey sent to Swedish municipalities, background data on municipalities from public statistics and interviews with representatives of 20 municipalities. Swedish formal adult education, which includes general, vocational and Swedish for immigrants courses, is a responsibility of the municipality, but courses are not necessarily organised internally by the municipality. The results show how adult education is enacted in different ways. There are systems for outsourcing courses to various other providers, typically private training companies. There are thus both private and public providers, but courses are paid for by the municipality, which is also responsible of quality assurance. The quality assurance is typically enacted with a focus on students, via surveys and statistics on outcomes, but quality measures also target providers. Swedish adult education is characterised by extensive marketisation with many private providers and a broad supply of courses, but the municipalities are experiencing quality problems among providers, and some municipalities are considering extending their internal provision. There is also a labour-market focus where training programmes to improve adults' employability are prioritised.
\end{abstract}

\title{
Keywords
}

Marketisation, adult education, municipality, procurement, authorisation, quality

\section{Introduction}

Marketisation and privatisation of public education are taking place in different ways across the world (Verger et al., 2017). Ball and Youdell (2008) have identified two main types of approach in such processes - exogenous and endogenous privatisation, which are

\section{Corresponding author:}

Per Andersson, Department of behavioural sciences and learning, Linköping University, 58I 83 Linköping, Sweden.

Email: per.andersson@liu.se 
also described as external and internal marketisation (Lundahl et al., 2013). External marketisation includes means such as private providers and procurement, while internal marketisation takes place when public organisations are managed in a more business-like way.

In our case, Sweden, there has been a strong trend of marketisation of the educational system in compulsory and upper secondary school, and formal adult education, in the last decades. Verger et al. (2017) identify a 'Nordic path' to privatisation, with neoliberal reforms of the welfare systems. However, the organisation and marketisation of Swedish adult education have decisive differences, as compared to the development with independent schools in compulsory and upper secondary school. But, in both cases, the 290 municipalities are responsible for providing this publicly funded education for their inhabitants. Our focus here is on the marketisation of municipal adult education (MAE), which includes formal education in general courses corresponding to the curricula for compulsory and upper secondary school, vocational courses at upper secondary level and courses in Swedish for immigrants (SFI). In 2019, 4.3\% of the adult population aged 2064 years took part in MAE, that is, 387,000 students, which means that there are currently more students here than in upper secondary school (SNAE, 2020a; 2020b).

Municipal adult education is governed by the Education Act 2010 and the Adult Education Regulation, 2011, and it also has its own national curriculum (SNAE, 2017). Teaching is organised as separate courses, and shorter training programmes preparing for a defined vocation, as compared to the 3-year programmes in upper secondary school. Municipalities are required to offer all applicants a study place when it comes to basic courses (corresponding to compulsory school) and SFI. The supply of courses should also be flexible, in terms of study pace, distance-course options and continuous admission. The municipalities must offer adult education opportunities, but may according to the law choose to contract external, private providers to organise part of or all MAE offerings. Still, the municipality is responsible for quality, and quality assurance, irrespective of the provider.

Based on the Public Procurement Act 2016:1145, 2016, a quasi-market has developed where many municipalities choose to conduct public procurements and contract private providers to organise courses, instead of, or complementary to, their internal, public providers (Fejes \& Holmqvist, 2019). During the last few years, an authorisation system similar to the independent schools (see below) has been developing in MAE, but here - as in the procurement system - the municipality decides what system for private providers to apply, if any, and the conditions for providers to be authorised. Furthermore, the municipalities must treat all providers who are tendering, or applying for authorisation, equally, based on the stated conditions for procurement or authorisation. An interesting difference, however, is that there is no applicable Swedish legislation governing the authorisation system, although it is subject to a judgement by the European Court of Justice (C-410/14) (EU Court, 2016) that is interpreted as an acceptance of this system.

In $2019,50 \%$ of the adult students in general and vocational courses, and $38 \%$ of the students in SFI courses, were enrolled in courses organised by a non-public provider. This can be compared to $15 \%$ of the students in compulsory school and $28 \%$ in upper secondary school being enrolled with an independent school (SNAE, 2020a, 2020b). 
Compulsory and upper secondary school have this nationwide system of independent schools, where private providers are authorised by the state to establish schools that compete with the public, municipal schools in recruiting pupils - and with a "voucher system' where the municipality is obliged to pay the independent schools the same amount of money per pupil that the public schools get. The development of MAE, as well as of compulsory and upper secondary school, could be understood as a combination of external and internal marketisation. There are private providers, competing in external quasi-markets, but the public schools - and administrative systems - are also strongly influenced internally by these ways of organising education.

The system of independent schools in compulsory and upper secondary school has been the main focus in prior research on marketisation in the Swedish school system (Dahlstedt \& Fejes, 2019). Market orientation and marketisation could reduce the need for state-led control, but also intensify this need. Rönnberg (2011) shows how the Swedish marketisation, with a quasi-market of independent schools, means both privatisation and decentralisation, and the development of more elaborate systems for state control. Furthermore, an ambition in policy to uphold equivalence and quality in the decentralised and marketised education system resulted in (a need for) more control, enacted, for example, in the reintroduction of national school inspections in Sweden (Rönnberg, 2012).

\section{Paths towards privatisation and marketisation}

The development in Sweden could, as mentioned, be understood as an expression of the Nordic path towards privatisation, one of the paths described by Verger et al. (2017), that is, as reforms within the framework of the welfare state. However, the voucher system is described as the most extreme example of this Nordic path, not so far from the second path where privatisation is part of a neoliberal state structural reform, where Chile and the UK are the best examples (Verger et al., 2017). A third path is identified as 'scaling up' of privatisation, like in the US, where the development is more diversified, without a statelevel reform. Further, there are other paths towards privatisation, where the historical private-public partnership is a fourth path relevant to the understanding of Swedish adult education in a broader sense. This path represents a development where religious and ideological interests have influenced the school system, such as in the Netherlands with a system of public funding to ,for example, religious groups who are allowed to manage their own schools (Verger et al., 2017), a development which is similar to the non-formal adult education enacted in Swedish folk high schools and study associations (see below).

\section{Marketisation in adult education}

Research on marketisation of adult education has mainly been conceptual or concerned with analysing policy (Fejes \& Olesen, 2016), while empirical studies of the consequences in the practice of adult education are sparse. Still, there are a few studies on the topic, and particularly studies of marketisation of Swedish adult education and its consequences. 
In the early 2000s, the case of restructuring and marketising adult education in a large municipality through procurement was described as the development of a market with the municipality as the customer, resulting in more private supply of education with public payment. The supply of adult education became more labour-market-oriented, but this did not give students greater freedom of choice. Rather, effects such as increased costs for administration, quality control and monitoring and less professional freedom for teachers, whose labour market is privatised to a high degree, could be seen (Beach, 2004; Beach \& Carlson, 2004).

The process of marketisation has challenged educational values in different ways. Runesdotter (2011) described the tensions that arose in Swedish folk high schools when the schools that traditionally organise non-formal adult education were involved in the competition for educational commissions in the formal system. The market-like structures meant an opportunity for them to get involved in the competition, but in this process, traditional institutional values connected to the more independent courses of the folk high school were challenged. Wärvik (2013) presented an example where a quality assurance scheme was introduced by an external vocational education and training (VET) provider in the restructured MAE. The scheme meant standardisation of educational content and assessment. It governed teachers' work, but also resulted in tensions concerning how the teachers were able to keep to their own vocational ideas and to adapt teaching to the special needs of individual students. Fejes et al. (2016) analysed how marketisation influenced students, teachers and principals in adult education. Their findings indicate that principals and students mainly conform to the demands that emerge, while teachers to a higher degree show resistance towards the institutional logics of a marketised system.

Bjursell (2016) identified different metaphors in school leaders' discourse about adult education. Education as learning, as market and as administration are the most common understandings that are expressed. Bjursell highlights how the metaphor of market represents the idea of a free market with negotiations between different parties, while the metaphor of administration represents the idea of 'a planned economy in which activities are embodied in a systematic and long-term action plan' (p. 203). This illustrates a tension between ideas of market and administration in adult education, parallel to the relationship between decentralisation and state control of education described by Rönnberg (2011, 2012). Bjursell et al. (2015) also show how the school leaders in adult education are occupied with the quality systems that are introduced as control mechanisms. To meet the challenge of quality assurance, Bjursell et al. discuss a typology, where administrative quality is separated from democratic and educational quality. Such a typology could make it possible to measure administrative quality, parallel to other types of quality work in the other dimensions that are more central for the aim of education.

Fejes and Holmqvist (2019) describe consequences of the marketisation through procurement in Swedish adult education. For example, the quality assurance system of the municipality becomes important. Short contracts could create instability, and stress among staff, when the conditions become different for teachers at public or private providers, for example, with more students per teacher at private providers, who have to compete for contracts through a low price, compared to the ratio at public providers. The 
procurement system not only means outsourcing but also that providers and teachers become replaceable commodities in a market.

Carlson and Jacobsson (2019) focus on the SFI courses, which they describe as characterised by a work orientation (making students employable) and an evaluation and monitoring culture, with 'diminished professional discretion in the pedagogical enterprise' (p. 134). The teachers describe a situation of high workload, bureaucratisation and marginalisation of pedagogy, and the conclusion is that 'adult education no longer nurtures its democratic and civic functions' (p. 135).

The rather limited research on marketisation of Swedish adult education is quite surprising bearing in mind that the quasi-market of adult education is large and encompasses a high percentage of all students. This article presents findings from a research project that studies the marketisation processes in Swedish adult education, and how adult education is organised at local level. A central concern of the present study is also how municipal responsibility for quality assurance is organised, irrespective of the provider.

The aim of the study is to analyse how the organisation of Swedish adult education is enacted at the local level. The article will answer the following research questions:

1. How is adult education enacted in different municipalities?

2. How is quality assurance in adult education enacted in different municipalities?

3. What character does the marketisation of adult education have in different municipalities?

\section{Policy enactment}

In this article, we are continuing the analysis of the policy enactment (Ball et al., 2012; Braun et al., 2010) in Swedish adult education (Holmqvist et al., 2021). From the perspective we apply, the process of enactment is complex and includes the interpretation and translation of policy by multiple actors in the local context into local practice (Ball et al., 2012). That is, the national policy does not prescribe exactly how MAE should be enacted. Instead, the policy has certain degrees of freedom, and local actors in the municipalities are interpreting the policy and translate it into their own models of organising adult education.

For example, Holmqvist et al. (2021) show how policy translation and enactment in procurement at the local, municipal level strongly influences the outcomes of marketisation of Swedish MAE. They compare two municipalities, where the one with focus on quality in the procurement can retain stronger control of the external provision than the one where price is the main factor for choosing providers.

\section{Methods}

This article includes the first parts of a larger study where the policy enactment is studied based on both qualitative and quantitative data. The study as a whole examines the organisation of MAE in Sweden from political decisions, via procurement or authorisation procedures, work with quality assurance, admission and selection of students, to 
how all this affects the students in municipal adult education, teachers' work and the classroom situation.

The data for this article consist of three parts. Firstly, a nationwide survey was distributed to representatives of adult education in all Swedish municipalities (290), with 164 responses representing 201 municipalities (69\%). (Some municipalities have a common organisation for MAE, and here one response represents more than one municipality.) Secondly, the survey data is supplemented by background data from public statistics on the character of the municipalities, providing the basis for some comparisons between different types of municipalities. Thirdly, qualitative interviews have been conducted with 20 representatives (school mangers and principals) of MAE in a sample of 20 municipalities, which were selected based on information from the first and the second step, to obtain a sample covering different types of municipalities as well as ways of organising MAE.

The quantitative data consisting of survey responses were analysed both statistically and thematically. The qualitative data consisting of interview responses have been transcribed and analysed thematically (e.g. Braun \& Clarke, 2006). Both the survey responses and the interview responses were then analysed in relation to the background data for the municipalities in order to be able to see trends and draw conclusions about the importance of, among other things, size of population and political governance.

The article uses comparative statistics in the form of percentages from the survey responses and descriptions and quotations from the interviews to illustrate the results. (All interviews were conducted in Swedish, and quotations have been translated into English.)

The survey results cover a large proportion of all municipalities in Sweden that conduct adult education, and the high response rate implicates a relatively high degree of reliability. However, there is always a risk that questions will be misinterpreted. To avoid this, during the 20 interviews in the third step, we provided feedback to the survey respondents and gave the respondents the opportunity to develop answers in the survey that were unclear or that indicated misunderstandings.

Concerning ethical issues, the survey is not anonymous regarding which municipality the answers come from; however, the anonymity of the people in the municipality who answered the survey has been preserved. We handle all data confidentially and are careful that it should not be possible to trace the empirical examples in the article to individual municipalities. The interviews are also handled confidentially, we have anonymised the respondents and do not report which municipalities are included among the 20 selected for interviews.

\section{Results}

\section{Organising adult education in different municipalities in Sweden}

As described in the introduction, there are more students in municipal adult education than in upper secondary school in Sweden. Most municipalities offer MAE in SFI, general courses at basic and upper secondary level, and VET courses and programmes at upper secondary level. 
The survey shows that $6 \%$ of the responding municipalities only use external providers in MAE. In $57 \%$ of the municipalities, MAE is arranged by a mix of both public and external adult education providers, which means that the latter have a strong position here too. $30 \%$ of the municipalities responded that they only or mainly use their own public providers/schools in MAE, but even here, individual students could take courses where the study places are purchased from external providers, or in other municipalities. The remaining $7 \%$ of the municipalities responded that they arrange MAE in other ways than the previous alternatives, ways which in the written responses are described as more complex patterns with a mix of public and private providers as well as cooperation with upper secondary school and other municipalities. Among the external providers, the education companies are dominant $-95.4 \%$ of the municipalities that have external providers hire such companies. The exceptions are mainly folk high schools and study associations, which are independent organisations owned by different NGOs or by the public regional organisation.

Selection of external providers. The opportunity of hiring external providers is typically enacted in a public procurement process. External providers are submitting tenders with descriptions of courses they want to organise, based on criteria decided by the municipality, and the price for this. Thereafter, the municipality chooses the provider with the lowest price that also fulfils the predefined criteria. However, some municipalities decide fixed prices for different types of course, which means that the selection is only based on quality criteria.

Some municipalities $(16.4 \%$ of those with external providers, who answered the survey) have more recently interpreted the policy differently, and translated it into the system of authorisation, with authorised independent providers and a local voucher system like in compulsory and upper secondary school. Here, the municipality decides the price for each course/student and defines criteria to be fulfilled for authorisation as a legitimate provider of the course. Providers apply for authorisation based on these conditions, and when the municipality has authorised the providers, they must recruit their students.

Motives for external providers via procurement/authorisation or own management of municipal adult education. The survey results show that the motive for almost all municipalities hiring external providers to some extent is to be able to offer a wider range of courses. A common motive for enactment in procurement is also to try to keep prices low through competition between education providers. However, this only works in larger municipalities where several providers compete to win the procurements. Principals from smaller municipalities which we have interviewed say instead that they often do not receive any response at all when they advertise MAE courses or training programmes for procurement, which means that the supply of, for example, VET courses is limited due to the lack of providers and the municipality not being able to offer the courses through internal provision. In the larger municipalities, the survey shows that it is instead common to let several providers offer courses or training programmes in the same area. This, the principals explain in the interviews, is to increase the flexibility in MAE by providing different variants of the 
same training programme that can meet the needs of different students. The enactment in terms of range of courses and training programmes can thus vary greatly depending on the municipality in which the adult student lives.

Although several of the interviewed principals can see advantages in organising MPA through procurement, some of them also point out that there are disadvantages that in some municipalities are considered so great that the municipalities plan to return a larger part of the MAE to public providers. The problems mainly concern organisational issues such as short contracts and appeals in procurement, but also issues directly relating to the quality of the education.

Procurement contracts usually only last for a couple of years, which does not provide sufficient long-term perspectives to build up courses or training programmes in areas that require expensive equipment. Short-term contracts also provide more precarious employment conditions for teachers, who have limited opportunities to work long-term with quality issues such as the development of courses and training programmes. It is also stated that appeals are common by the companies that have lost the procurement. Appeals are costly for municipalities to handle, and this leads to the programmes not being able to start according to plan; a principal says:

The law on public procurement with four-year contracts is bad for our schools. The law is not adapted to procure educational services, there should be a better system for creating better education for students. Four years is very short-term, making it work is a big challenge. A lot of resources go into this, appeals, and so on.

In addition to the problems surrounding the procurement procedure itself, there are also several municipalities, both in the survey and in the interviews, that state it is cheaper to conduct courses and training programmes internally. The municipalities can then achieve synergies by coordinating with upper secondary school and also easier adapt the educational activities if the number of students falls. Our study indicates that it is primarily smaller municipalities that want to avoid committing themselves to procurement agreements because they are more sensitive to fluctuations in the number of students. Because of this, they translate the policy into an enactment where they offer courses and training programmes under their own auspices to a greater extent, which creates more flexibility.

It also happens that external education companies that municipalities hire for adult education go bankrupt. One principal says: 'when education companies go bankrupt, you realise that there can be big problems, it was a huge challenge for us to manage the situation when a company went bankrupt during ongoing training'. The biggest problem is that the municipality must be able to arrange so that students can continue their training programme with another provider, which can be difficult to solve if there is only one provider in the municipality that offers the programme, or if there are no vacancies in the programme at another organiser. There is also no guarantee that it is possible to 'jump into' a training programme with a new provider at the same level where the students were in the programme. For educational companies to have a sufficiently large student base to be profitable, some providers have a wide admission area with students from several 
different municipalities on the same courses. Problems described with this are that the municipalities have different procurement periods and if a provider loses a procurement in one municipality, it risks going bankrupt in another municipality during the current period, when there is a sudden decrease in students.

In order to obtain more long-term and stable MAE and avoid the problems surrounding the procurement procedure and the risk of appeals, the survey and the interviews show that some municipalities, as mentioned above, have switched to an enactment through authorisation instead of procurement. Authorisation provides the opportunity for longerterm contracts, which is expected to lead to a more stable supply of providers. Authorisation is therefore considered to provide better conditions for developing courses and training programmes with raised quality. The fact that the providers are forced to operate in a more demand-driven way in the authorisation model, and the student becomes more like a customer compared to the procurement system, also means - according to principals and school managers we have interviewed - that education companies are forced to maintain the quality of their education in order to get a good reputation.

However, in the interviews, some principals and school managers express doubts about the authorisation model, mainly relating to a fear of over-establishment. In the case of authorisation, the municipality is not allowed to say no to a provider who meets the municipality's requirements for authorisation. This means a risk that many providers will offer the same courses and training programmes, which can cause great competition to attract students and lead to few students with certain providers. One municipality states in the survey, for example, that they have 30-40 different providers offering 4000 courses and 600 training programmes. Over-establishment leads to providers risking bankruptcy even within the authorisation system. Some of the interviewed school leaders however think that the market is self-regulating and that competition raises the quality by the providers having to 'sharpen up' their education and, for example, offer profiles or specialisations that attract students.

Local political decisions on the organisation of municipal adult education. In addition to the reasons already mentioned, the question of whether MAE should primarily be run by internal, public providers or by external providers hired through procurement or authorisation, also has a political ideological dimension seen in the interpretation of policy. During the interviews it appears that several right-wing- governed municipalities advocate that a large part, or all, of the MAE should be conducted by educational companies. In some municipalities that were previously under right-wing rule, there has been a political shift to social democrats which, in interviews with principals and school managers, is described as a reason why the municipality is planning changes towards MAE being provided internally to a greater extent.

Although there is a political interest in how adult education should be organised at an overall level, several school leaders say that the enactment of MAE is not politically prioritised compared to compulsory and upper secondary school. Even though in many municipalities there are more students in MAE than in upper secondary school, the latter is given significantly more attention in the political debate. It is often a responsibility resting 
on individual school managers or principals within MAE to show politicians that MAE 'exists' and to pursue various issues. A principal says:

I get 10 minutes to talk about my activities before the political committee and in that time I can only mention a fraction of our activities. Politicians do not see the whole of our business. The decisions come from the principal, not politicians, even though I have almost twice as many students in MAE compared to upper secondary school.

It also emerges in the interviews that several municipalities want to have a stronger connection between MAE and the labour market and have therefore made political decisions meaning a new translation of policy that is enacted by moving adult education issues from the education office to the labour-market office. However, this is perceived as further reducing the interest in politically discussing pedagogical issues concerning MAE.

Previously, we belonged to the education office, but since 2011 we have come under the labour market office. That brought more of a focus on us, clearer assignments, more connection to the labour market. In the huge education administration, adult education had become a bit of an odd bird, but the disadvantage is that the education office has more extra resources and a greater interest in educational issues.

Widespread cooperation between municipalities. In enactment of adult education, collaborations between municipalities are very common. The survey shows that virtually all municipalities (99\% of those who responded) participate in a national initiative for vocational adult education (VAE). This subsidy was introduced in 2009 with the aim of increasing the supply of vocational education in MAE through regional cooperation between at least three municipalities and thereby counteracting a shortage of vocationally educated labour (Regional Vocational Adult Education Regulation, 2016). There has also been an option to apply for subsidies for a combination of VET courses and courses in SFI, as a response to the high number of refugees that have arrived in Sweden in recent years, with similar conditions and requirements for cooperation as for VAE.

Although there are requirements for cooperation between municipalities in order to receive subsidies, the survey and interview results show that these requirements are interpreted and translated in different ways, where cooperation can be enacted at very different levels. Some municipalities only write applications together, without really having any collaboration around the education. But some municipalities have a more developed system for collaboration in regional associations where students from several municipalities can apply for courses to whichever municipality they want within a region. In addition to the possibility of receiving subsidies, the municipalities primarily collaborate with each other in order to be able to offer a wider range of courses. Smaller municipalities can also work together to make MAE more efficient by having common staff, for example, teachers who travel between municipalities or shared curators and study counsellors. Some municipalities also work with common systems for quality assurance and marketing of MAE and together conduct inventories of the needs in the 
labour market. This is used to avoid too much competition between nearby municipalities, which may risk there not being enough students for the courses.

Priority programmes. The national initiatives that the municipalities can apply for as well as requirements to offer all applicants places within, for example, the basic courses and SFI, affect the supply within MAE. Due to the large group of immigrants who came to Sweden during the 2010s, SFI has for several years constituted a large part of MAE. Enacting the requirement to offer all applicants a place within SFI is described by several principals as a challenge, partly due to economic factors but also lack of teachers and training facilities. This has forced most municipalities to hire external providers for SFI.

In addition to SFI, training programmes are prioritised to a large extent according to the needs of the labour market. One principal says: 'We address areas in which employers express a shortage of labour. We follow the employment service and the regional union's forecasts.' In several municipalities, political decisions have also been made about which training programmes should be prioritised, and often it is a matter of providing one's own municipal activities with labour, for example, in elderly care and childcare.

Virtually all municipalities in the survey and the interviews also interpret and translate the requirement of flexibility into offering some form of distance education. Often students can choose to study vocational courses, general theoretical courses and SFI at a distance.

The arguments for enactment in distance courses are mainly to provide a larger range of courses, as well as increased flexibility and accessibility. Distance courses organised by external providers often have a larger admission area and thanks to many municipalities using distance alternatives with external providers, there is often more than one provider available for a course or an entire training programme, which means good opportunities for students to get a place on the training they want in MAE. However, there are also problems with the enactment in distance education according to several of the interviewed principals, mainly due to a lack of quality which means that the students do not get the knowledge they need to be prepared for further studies or work. Principals also tell of a growing group of students who apply for distance education because they think it is easier or think it is nice not to have to go to school. Many of these students, however, have difficulty to studying 'independently' without the support of a teacher.

\section{Quality assurance in adult education}

Most municipalities included in our study use several methods for enacting quality assurance of MAE. The most common methods are student surveys (used in $84 \%$ of responding municipalities) and statistics concerning output (78\%). In addition to this, quality assurance is conducted through report meetings $(62 \%)$, written reports from providers (54\%) and surveys sent to providers (42\%). Answers to open questions in the survey also show that there is quality assurance through statistics of grades and follow-up of employment rates after studying in MAE. Perhaps more surprisingly, only just under half $(49 \%)$ of the respondents have answered that they do conduct on-site inspections of external providers. 
Despite the use of several methods for quality assurance, many of the interviewed school managers and principals describe difficulties to get an overview of the courses run by external providers and thus difficulties to guarantee good educational quality for MAE. Principals give examples of external providers that have so poor quality in their training programmes that the students are neither prepared for further studies nor work.

Difficulties that are pointed out in the quality assurance include following up the complaints made by students and that some providers are cheating with grading, which means that students come to courses and have grades from previous courses without having knowledge corresponding to what is expected from the grades. A person responsible for MAE writes in the survey responses that: 'Every time this happens, I break down a little. I have lots of similar examples. It's really, really tough then to keep flying the flag'. Another quality problem that the principals within MAE testify to is the lack of qualified teachers. A principal says: 'We mainly have SFI under our own auspices. This is because we discovered that some providers did not live up to the requirements and did not have qualified teachers, even though they had claimed that they did'. Although several of the interviewed principals testify to problems with the enactment of quality of education, and cheating of various kinds at some of the external education providers, most of the municipalities that have answered the survey $(68 \%)$ have not taken any specific measures based on the quality assurance work. In cases where sanctions are applied due to a lack of quality, these may involve setting up an action plan, issuing a fine, discontinuing admissions or termination of the contract. In several cases, municipalities have enacted the policy of quality by returning courses to their public providers to gain control over the quality of the courses.

What is considered quality in municipal adult education and how is it followed up? The principals' interpretation of what defines good quality in MAE is largely about the education being flexible and adapted to the individual's needs, which is partly enacted by being able to offer a wide range of courses with admission several times per semester, and partly by being able to offer both on-site education, half-distance and full-distance. Quality is also interpreted as involving courses and training programmes that meet labourmarket needs and make students ready to move into employment.

Both the survey and the interview responses show that several municipalities instead of going for the lowest price when procuring now have a stronger focus on quality and have worked out clear requirements that the providers must meet. This changed translation and enactment of policy has come after many problems with external providers have been identified. A principal says: 'Nowadays it is quality that applies rather than the lowest price. In the past the price was a major governing factor. Now there has been a realisation that you have to look more at the qualitative aspect'.

In order to reduce the problems described above, principals describe in the interviews how municipalities in the procurement process translate quality into requirements of, among other things, qualified teachers, access to digital resources, access to internships in VET, and that national exams are conducted on site at the school and used as part of grading. A principal says: 'When we saw that the provider did not have national exams, it 
was documented and added to the new procurement. They had also neglected to arrange internships in line with their contractual obligations'.

To ensure that the policy on quality is enacted among external providers, some principals describe in the interviews that municipalities also have developed systems of payment that are based on the providers receiving a certain proportion of the money during the education, with a final payment if the students also achieve a passing grade. There is also a 'bonus system' if students complete their education within a certain number of weeks, which aims to promote rapid throughput.

\section{Discussion - the character of marketisation}

The results show that Swedish MAE is a heterogenous business with a broad variation in the interpretation and translation of policy into enactment, for example in different ways of implementing procurement and controls (cf. Holmqvist et al., 2021). Marketisation is present in different ways in the enacted practice of adult education (cf. Verger et al., 2017). Even with a high number of external providers, privatisation and marketisation in Swedish adult education takes place within the path of a Nordic welfare system, with extensive study opportunities without fees. Policy initiatives on state level that resulted in structural reforms with widespread procurement in MAE, could be seen as neoliberal initiatives, if not mainly with a voucher system, where the municipality becomes the customer procuring and buying education from private providers. However, the local freedom in enactment even resembles the more diversified path of 'scaling up' privatisation, with extensive differences between municipalities. It should also be noted that Sweden has a parallel system of non-formal, publicly funded, adult education in the abovementioned folk high schools and study associations, existing since the late 19th century, a system more similar to the path of public-private partnership. These are involved as external providers in formal MAE, in addition to their main function in nonformal adult education (cf. Runesdotter, 2011).

As mentioned, empirical studies of marketisation in adult education are sparse, and they mainly concern the development in Sweden. Therefore, we will discuss the character of policy enactment in marketisation of Swedish adult education, and its consequences, as a case of general interest beyond the national context.

To fulfil the requirement of flexibility and continuous intake in MAE, and to be able to offer a broad range of courses, almost all Swedish municipalities have contracted external providers to some extent. Some of them solely have external providers, but more common is to have a combination of internal, public provision and external, private provision. The high number of external providers results in an enactment of the flexibility policy with an extensive supply of courses with a freedom of choice for the students regarding study pace and form, and good opportunities for adults to be admitted to VET as well as general courses. But, as previous research shows, external marketisation is accompanied by a great deal of administration and need for quality control (Bjursell, 2016; Bjursell et al., 2015; Fejes \& Holmqvist, 2019; Rönnberg, 2011, 2012). Short-term contracts make it difficult to plan, and the risk of over-establishment is another problem. It also happens that 
private providers go bankrupt, which might cause severe problems for the responsible municipality, as well as for the affected students.

The external providers are typically large education companies that are contracted to organise adult education in many municipalities in different parts of Sweden. Many of them offer distance courses, where they work for many municipalities. Most municipalities contract the providers through public procurement, but there is a tendency increasing application of the authorisation system, a way of scaling up privatisation with long-term contracts. This means that they avoid repeated procurement processes, appeals from providers who do not get the contract, and not the least the short-term contracts. However, there is also a tendency of 'scaling down' in smaller municipalities which resume internal provision, to achieve better stability and flexibility, and to avoid quality problems among unprofessional external providers.

\section{Municipal adult education - not a priority for learning and education, but as a labour-market measure}

As mentioned, Swedish MAE is extensive, with more students than upper secondary school, but still the school managers do not experience adult education as a political priority, compared to compulsory and upper secondary school. School managers and principals often have to take responsibility and pursue their own causes, inviting themselves to their political committee to discuss current issues and development, that is, putting themselves on the agenda. A number of principals also consider democratic and educational values being challenged, or at least put in the background (cf. Fejes et al., 2016; Runesdotter, 2011; Wärvik, 2013). Instead, a clear labour-market orientation is visible in MAE, which is not a new experience (cf. Beach, 2004; Beach \& Carlson, 2004). This is expressed for example by moving adult education issues from the education office to the labour-market office. This orientation where adult education becomes an enactment of labour-market rather than education policy is also visible in political prioritisations in favour of vocational education, and the school managers and principals describe this as a top priority of 'getting people into work'. MAE is also described as an important part of the enactment of integration policy, with priority given to employment here too (cf. Carlson \& Jacobsson, 2019). A number of municipalities have programmes where SFI is combined with VET, and in some cases there are even proposals that SFI must be combined with VET.

Almost all municipalities prioritise training opportunities in areas with a shortage of labour in the internal, municipal organisation such as in elderly and child care, and many students in these areas are immigrants, as this is training that results in good employment opportunities. However, this way of enacting labour-market and integration policy also means a low degree of freedom of choice for the individual (Beach \& Carlson, 2004).

\section{Economic insecurity and short-term contracts}

There are also responses suggesting resource shortages in MAE. Ambitious policies are not always translated into resources that make the intended enactment possible. The 
challenges include taking care of a growing group of low-educated students with language deficiencies, and a growing group of students with special needs, without extra resources to employ more teachers. This could be compared to what Fejes and Holmqvist (2019) show concerning more students per teachers at private providers, which can result in students having less one-to-one time with the teacher, and in the long run poorer study results. This situation has been described by a number of school managers in our study too, particularly in distance education, which often means comparably little time with the teacher. There are also problems in recruiting qualified teachers, due to a lack of teachers and unattractive terms of employment and work conditions, for example, based on enactment in procurement with providers' short-term contracts that could cause stress among the staff.

A number of different state policies include subsidies for initiatives in MAE, for example, the national VAE initiative that has required cooperation between municipalities regarding MAE and has increased the opportunities for adults to gain admission to VET. Principals point out that they are dependent on the state subsidies to be able to run their business, but that long-term planning is difficult when such policies and subsidies are decided on short terms from year to year, which also causes stress (cf. Fejes \& Holmqvist, 2019). There is also a requirement for co-financing from the municipalities to receive the subsidies. The model used for this is described as very costly for smaller municipalities, which limits the study places in VAE. In some cases, municipalities applying for subsidies together have tried to solve the problem through the enactment of a 'Robin Hood model' where the larger municipalities have taken more extensive responsibility for co-financing. They can thereby establish cooperation with smaller municipalities, and together they can broaden the supply of adult education.

\section{Quality assurance - a key element in municipal adult education}

A large number of providers in MAE also places high demands on quality assurance. Administration in terms of policy enactment through quality assurance becomes the other side of the coin of external marketisation. An important question here is to what degree the quality assurance places a focus on the central dimensions of educational and democratic quality, or whether it is the administrative quality that is measured (Bjursell et al., 2015).

The study shows that the quality assurance is to a high extent 'student centred' with a focus on students' satisfaction, and statistics concerning output. Education that fulfils labour-market needs and results in employment is also defined as quality. Several methods are applied for quality assurance, including surveys of students and providers, written reports from providers and statistics on, participation, study results etc. Quality assurance is thus often enacted by focussing the administrative quality (Bjursell et al., 2015), that is, that administrative procedures and rules are followed, rather than educational quality. For example, it is not very common to conduct on-site inspections of the providers and observe lessons for quality assurance.

Despite the use of several methods for quality assurance, a number of school managers find it difficult to maintain control over the external providers and guarantee educational quality. They report cheating and quality problems being discovered at some external 
providers, for example lack of qualified teachers, cheating in grading, or even such a lack of quality that the students do not obtain a good enough knowledge foundation either for employment or for further studies. As a consequence of this, a number of municipalities have introduced a system of enactment with procurement based on quality rather than price (cf. Holmqvist et al., 2021). Some municipalities have also introduced a bonus system where the provider does not receive final payment until the student has passed. In some cases, a municipality that contracts external providers who work for several municipalities might even pay more than the others do, on the understanding that they expect higher outcomes among their own students.

\section{Conclusion}

If policies of privatisation and marketisation are to be enacted in other adult education systems, there are lessons to be learnt from the development in the Swedish case. However, what lessons that are relevant in such enactment depends on the specific path towards privatisation that is taken. If privatised adult education is still publicly funded, quality assurance certainly becomes a key element, but then it is critical to keep focus on educational and democratic quality, and not only on administrative quality and efficiency. A certain level of resources is necessary to make quality possible. There might also be options of short-term or long-term contracts, with pros and cons depending on the local situation. And learning and education should remain in focus, even if labour-market and integration policies also are to be enacted in adult education.

\section{Declaration of conflicting interests}

The authors declared no potential conflicts of interest with respect to the research, authorship, and/or publication of this article.

\section{Funding}

The authors disclosed receipt of the following financial support for the research, authorship, and/or publication of this article: This work was supported by the Swedish Research Council under Grant number 2017-03603.

\section{ORCID iDs}

Per Andersson (D) https://orcid.org/0000-0003-1194-9708

Karolina Muhrman (D) https://orcid.org/0000-0001-7990-8684

\section{References}

Adult Education Regulation. (2011). SFS 2011:1108. Swedish Parliament.

Ball, S. J., Maguire, M., \& Braun, A. (2012). How schools do policy: Policy enactments in secondary schools. Routledge.

Ball, S. J., \& Youdell, D. (2008). Hidden privatization in public education. Education International. 
Beach, D. (2004). The public cost of the re-structuring of adult education: A case in point from Sweden. The Journal for Critical Education Policy Studies, 2(1), 159-188.

Beach, D., \& Carlson, M. (2004). Adult education goes to market: An ethnographic case study of the restructuring and reculturing of adult education. European Educational Research Journal, 3(3), 673-691. https://doi.org/10.2304/eerj.2004.3.3.9

Bjursell, C. (2016). When theories become practice: A metaphorical analysis of adult-education school-leaders' talk. European Journal for Research on the Education and Learning of Adults, 7(2), 191-205. https://doi.org/10.3384/rela.2000-7426.rela9084

Bjursell, C., Chaib, C., Falkner, C., \& Ludvigsson, A. (2015). Kvalitetsarbete $i$ vuxenutbildning [Quality work in adult education]. Encell rapport 1:2015. Nomen förlag.

Braun, A., Maguire, M., \& Ball, S. J. (2010). Policy enactments in the UK secondary school: Examining policy, practice and school positioning. Journal of Education Policy, 25(4), 547-560. https://doi.org/10.1080/02680931003698544

Braun, V., \& Clarke, V. (2006). Using thematic analysis in psychology. Qualitative Research in Psychology, 3(2), 77-101. http://dx.doi.org/10.1191/1478088706qp063oa

Carlson, M., \& Jacobsson, B. (2019). Neoliberalising adult education. In M. Dahlstedt, \& A. Fejes (Eds.), Neoliberalism and market forces in education: Lessons from Sweden (pp. 123-137). Routledge.

Dahlstedt, M., \& Fejes, A. (Eds.) (2019). Neoliberalism and market forces in education: Lessons from Sweden. Routledge.

Educational Act (2010), SFS 2010:800. (2010). Swedish Parliament.

EU Court. (2016). Judgment C-410/14 Falk Pharma. http://curia.europa.eu/juris/document/document. jsf?text $=\&$ docid $=179464 \&$ pageIndex $=0 \&$ doclang $=$ EN\&mode $=1$ st \&dir $=\&$ occ $=$ first $\&$ part $=$ $1 \&$ cid $=595457$

Fejes, A., \& Holmqvist, D. (2019). Procurement as a market in adult education. In M. Dahlstedt, \& A. Fejes (Eds.), Neoliberalism and market forces in education: Lessons from Sweden (pp. 156-169). Routledge.

Fejes, A., \& Olesen, H. S. (2016). Editorial: Marketization and commodification of adult education. European Journal for Research on the Education and Learning of Adults, 7(2), 146-150. http://dx.doi.org/10.3384/rela.2000-7426.relae12

Fejes, A., Runesdotter, C., \& Wärvik, G.-B. (2016). Marketisation of adult education: Principals as business leaders, standardised teachers and responsibilised students. International Journal of Lifelong Education, 35(6), 664-681. https://doi.org/10.1080/02601370.2016.1204366

Holmqvist, D., Fejes, A., \& Nylander, E. (2021). Auctioning out education: On exogenous privatisation through public procurement. European Educational Research Journal, 20(1), 102-117. https://doi.org/10.1177/1474904120953281

Lundahl, L., Erixon Arreman, I., Holm, A.-S., \& Lundström, U. (2013). Educational marketization the Swedish way. Education Inquiry, 4(3), 497-517. https://doi.org/10.3402/edui.v4i3.22620

Public Procurement Act 2016:1145. (2016). SFS 2016:1145. Swedish Parliament.

Regional Vocational Adult Education Regulation. (2016). SFS 2016:937. Swedish Ministry of Education.

Rönnberg, L. (2011). Exploring the intersection of marketisation and central state control through Swedish National School Inspection. Education Inquiry, 2(4), 689-707. https://doi.org/10. 3402/edui.v2i4.22007 
Rönnberg, L. (2012). Reinstating national school inspections in Sweden: The return of the state. Nordic Studies in Education, 32(2), 69-83.

Runesdotter, C. (2011). Tensions in the meeting between institutional logics and identities in Swedish Folk high schools. Education Inquiry, 2(4), 659-670. https://doi.org/10.3402/edui. v2i4.22005

SNAE (Swedish National Agency of Education). (2017). Läroplan för vuxenutbildningen. Reviderad 2017 [National curriculum for adult education. Revised 2017]. SNAE.

SNAE. (2020a). Elever och studieresultat $i$ kommunal vuxenutbildning 2019 [Students and results in MAE year 2019]. SNAE.

SNAE. (2020b). Sök statistik om förskola, skola och vuxenutbildning [Search statistics on preschool, school and adult education]. https://www.skolverket.se/skolutveckling/statistik/sokstatistik-om-forskola-skola-och-vuxenutbildning

Verger, A., Fontdevila, C., \& Zancajo, A. (2017). Multiple paths towards education privatization in a globalizing world: A cultural political economy review. Journal of Education Policy, 32(6), 757-787, https://doi.org/10.1080/02680939.2017.1318453

Wärvik, G.-B. (2013). The reconfiguration of adult education VET teachers: Tensions amongst organisational imperatives, vocational ideals and the needs of the students. International Journal of Training Research, 11(2), 122-134. https://doi.org/10.5172/ijtr.2013.11.2.122 